\title{
IN VITRO SCREENING OF ANTIOXIDANT PROPERTIES OF TEN CAMEROONIAN MEDICINAL PLANTS
}

Jules Clement Nguedia Assob ${ }^{1}$, Abdel Jelil Njouendou ${ }^{2,5}$, Pepin EfouetAlango Nkeng ${ }^{3}$, Jean Rodolphe Chouna ${ }^{3}$ (chounajr@yahoo.fr), S.M. Badami ${ }^{4}$ (shribadami@rediffmail.com), Veeresh P Verapur ${ }^{4}$ (veeresh36@gmail.com), B.D. Typpeswamy ${ }^{4}$ (t_swamy@hotmail.com) and Samuel Wanji ${ }^{2,5}$ (swanji@yahoo.fr).

1- University of Buea, Faculty of Health Sciences, P.O. Box 63, Buea Cameroon juleclement@yahoo.fr

2- University of Buea, Faculty of Sciences, P.O. Box 63, Buea Cameroon ajnjouendou@gmail.com

3- University of Dschang, Faculty of Sciences, Department of Chemistry, P.O.Box 67, Dschang Cameroon pnfalango@yahoo.fr

4- SreeSiddaganga College of Pharmacy, Tumkur, Karnataka, India

5- Research Foundation for Tropical disease and environment (REFOTDE), P.O. Box 474, Buea Cameroon

\section{ABSTRACT}

Background: Oxidative stress is involved in the pathogenesis of several degenerative diseases. This work studied the in vitro anti-oxidative properties of methanolic extracts of 10 Cameroonian medicinal plants including Autranellacongolensis (AC); Beilschmiediaanacardioides(BA); Crossopteryxfebrifiga (CF); Cussoniaarborea (Cu A); Cyphostema adenaucaule (Cy A); Dissotislongipetala (DL); Lonchocarpussepium(LS); Naucleapobeguinii (NP); Pycnanthusangolensis (PA); Picralimanitida (PN) used in folk medicine against various ailments associated with oxidative damages pattern. Method: The extracts were subjected to phytochemical screening to identify major classes of secondary metabolites. Their total contents in phenols, flavonoids were determined; whereas the anti-oxidative and reducing power were evaluated. These extracts were tested for their scavenging activity using DPPH, ABTS, superoxide, hydroxyl and nitric oxide radicals and hydrogen peroxide. The inhibitory effects of extracts against lipid peroxidation were also investigated on rat brain homogenates. Results: The methanolic extracts of CF, DL, LS and AC showed important antioxidant activities and scavenging properties against all radicals system used. The extract of CuA and NP were inactive against hydrogen peroxide. The most potent antioxidant activity was obtained with AC extract, which showed the lowest IC50 value as compared to the standard. The IC50 values of this extract were $7.31 \pm 0.25,5.20 \pm 0.35,42.17 \pm 0.60,77.30 \pm 7.41$, $32.94 \pm 1.32,9.71 \pm 1.07$ and $121.59 \pm 1.08 \mu \mathrm{g} / \mathrm{ml}$ against ABTS, DPPH, hydrogen peroxide, inhibition of lipid peroxidation, superoxide radical, hydroxyl radical and nitric oxide radical system respectively. These values were found to be comparable to those obtained with the standards. Significant positive correlations were observed between total antioxidant activity with total reducing power $(p<0.01 ; R 2=0.8190)$, total flavonoids $(P<0.05 ; R 2=0.6419)$ and total phenol $(P<0.01$; $\mathrm{R} 2=0.8643$ ); whereas non-significant correlation was obtained between other systems and the total phenolic constituents. Conclusion: The data generated from this study sustained the use of these medicinal plants in the treatment of various diseases associated with oxidative stress. The potent antioxidant activity of the Autranellacongolensis extract and its high content in phenolic constituents are to be taken into the consideration for further phytochemical and biological investigations.

\section{Indexing terms/Keywords}

Oxidative stress; phenols; medicinal plants; Autranellacongolensis; antiradical properties.

\section{Academic Discipline And Sub-Disciplines}

Phytopharmacology.

\section{SUBJECT CLASSIFICATION}

Biochemistry.

TYPE (METHOD/APPROACH)

Quasi-Experimental.

\section{Council for Innovative Research}

Peer Review Research Publishing System

Journal: JOURNAL OF ADVANCES IN BIOTECHNOLOGY

Vol 3, No 2.

www.ciribt.org , jbteditor@gmail.com 


\section{INTRODUCTION}

Oxidative stress contributes to the pathogenesis of several diseases including infectious and metabolic pathologies. Cancers, diabetes mellitus, liver injuries, aging, cardiovascular diseases, inflammation and neurodegenerative disorders form the majority of these pathologies [1-4]. The stress results from overproduction of reactive oxygen species (ROS) called pro-oxidant species or the failure of antioxidant defence systems leading to the destruction of biological macromolecules such as proteins, lipids and nucleic acids [5]. Antioxidants neutralize the destructive effect of ROS when they come in contact together and stop the degenerative chain reaction of free-radical oxidation, thus preventing or repairing oxidative damages of tissues [6]. If there are insufficient quantities of antioxidants to match its exposure to free radicals, then the body is said to be in a state of oxidative stress. In this state, unimpeded free radicals cause damage that can lead to inflammation, immune dysfunction, DNA damage and, potentially, a whole range of degenerative diseases [7].

A network of antioxidants known as the antioxidant defence system works together to maintain an effective protection of cells from free radical damages. This network involves biological reducing agents or scavengers which can be synthesized by the body such as coenzyme $\mathrm{Q}$, glutathione, peroxidases, and superoxide dismutase and catalase which play a key role in emergency defence of cells. The extrinsic antioxidant defence system involves dietary antioxidants and drugs. Such antioxidants include vitamins $\mathrm{E}$ and $\mathrm{C}$, alpha-lipoic acid, carotenoids, flavonoids, tannins and other dietary phenol derivatives [7]. Plants constitute the main source of extrinsic antioxidants as well as some effective drugs. It is important to investigate the antioxidant profiles of natural species used in the treatment of some diseases' complications. Several medicinal are used in the folk medicine in the treatment of various ailments associated with degenerative effects, but in most cases their antioxidant properties have not yet been established. Based on literature search, ten (10) Cameroonian medicinal plants used in the treatment of diseases whose pathogenesis involves oxidative stress were selected (table 1). The present study aimed at contributing in the evaluation of their mechanism of action in vitro.

\begin{tabular}{|c|c|c|c|c|}
\hline $\begin{array}{c}\text { Plants } \\
\text { (botanic name) } \\
\text { And Family }\end{array}$ & $\begin{array}{l}\text { Voucher } \\
\text { Number }\end{array}$ & $\begin{array}{l}\text { Part } \\
\text { used }\end{array}$ & $\begin{array}{l}\text { Extracti } \\
\text { on yield } \\
(\%)\end{array}$ & Medicinal properties \\
\hline $\begin{array}{l}\text { Autranellacongolensis } \\
\text { (AC) } \\
\text { Sapotaceae }\end{array}$ & $39458 / \mathrm{HNC}$ & Bark & 11.40 & Diarrhea and chronic dysentery, malaria $[8,9]$ \\
\hline $\begin{array}{l}\text { Beilschmiediaanacardioid } \\
\text { es (BA) Lauraceae }\end{array}$ & 32975/HNC & Bark & 12.50 & $\begin{array}{l}\text { Uterine tumours, rubella, rheumatisms, bacterial } \\
\text { and fungal infections [10] }\end{array}$ \\
\hline $\begin{array}{c}\text { Crossopteryxfebrifuga (CF } \\
\text { Rubiaceae }\end{array}$ & 39970/HNC & Bark & 7.43 & $\begin{array}{l}\text { Painful inflammatory disorders, fever, malaria, } \\
\text { trypanosomiasis }[11,12]\end{array}$ \\
\hline $\begin{array}{c}\text { Cussoniaarborea }(\mathrm{Cu} \mathrm{A}) \\
\text { Araliaceae }\end{array}$ & 39978/HNC & Bark & 13.43 & $\begin{array}{l}\text { Leprosy, Snakebite, malaria and constipation[13- } \\
15]\end{array}$ \\
\hline $\begin{array}{l}\text { Cyphostema adenaucaule } \\
\text { (Cy A) Vitaceae }\end{array}$ & 51976/HNC & Bark & 16.97 & Stomachache [16] \\
\hline $\begin{array}{l}\text { Dissotislongipetala (DL) } \\
\text { Melastomataceae }\end{array}$ & 40925/HNC & Bark & 9.00 & Nerve disorders $[17,18]$ \\
\hline $\begin{array}{l}\text { Lonchocarpussepium (LS) } \\
\text { Fabaceae }\end{array}$ & 76230/HNC & Bark & 8.00 & $\begin{array}{l}\text { Antifungal, expectorant, sedative, suppurative. } \\
\text { Madre de cacao is a folk remedy for alopecia, } \\
\text { boils, bruises, burns, colds, cough, debility, } \\
\text { eruptions, erysipelas, fever, fractures, gangrene, } \\
\text { headache, itch, prickly heat, rheumatism, skin } \\
\text { tumours, ulcers, urticaria and wounds [19]. }\end{array}$ \\
\hline $\begin{array}{l}\text { Naucleapobeguinii (NP) } \\
\text { Rubiaceae }\end{array}$ & $504710 / \mathrm{HNC}$ & Bark & 10.98 & Malaria $[20]$ \\
\hline $\begin{array}{c}\text { Pycnanthusangolensis } \\
\text { (PA } \\
\text { Myristicaceae }\end{array}$ & $628121 / \mathrm{HNC}$ & Seeds & 53.33 & $\begin{array}{c}\text { Hypercholesterolemia, type } 2 \text { diabetes, cancer, } \\
\text { Bile and liver complaints, } \\
\text { Stomachache [17] }\end{array}$ \\
\hline $\begin{array}{l}\text { Picralimanitida (PN) } \\
\text { Apocynaceae }\end{array}$ & $565411 / \mathrm{HNC}$ & Bark & 14.08 & $\begin{array}{c}\text { Analgesic, anti-inflammatory, diarrhea, fevers, } \\
\text { gonorrhea, hypertension, intestinal worms, } \\
\text { jaundice, malaria, trypanosomiasis and others } \\
\text { protozoa diseases [8] }\end{array}$ \\
\hline
\end{tabular}

\section{MATERIAL AND METHODS Plant material}

The plants were harvested in different localities of Cameroon and identified at the National Herbarium of Cameroon (NHC) where voucher specimens were deposited with voucher number. Detailed information on each medicinal plant is given in table 1. 


\section{Preparation of extracts}

Fresh plant materials were collected and dried at room temperature in an aerated laboratory, they were ground to yield a powder; five (05) kg of the powder were soaked in $13.5 \mathrm{~L}$ of methanol for 48 hours to give about $7.5 \mathrm{~L}$ of extract after filtration. The filtrate was evaporated on a rotary evaporator to obtain the different crude extracts, and the extraction yields were recorded (table1). An aliquot of each crude extract obtained was used for antioxidant tests while the remaining fraction was kept for further studies.

\section{Qualitative tests: phytochemical screening}

Qualitative phytochemical tests were performed for methanolic extracts of all plants to identify the various classes of phyto-constituents. These tests were performed according to the standard protocol as described below [21-23].

Test for Carbohydrates: Carbohydrates were identified by Mohlisch's test. Two drops of a-naphthol solution in alcohol was added in $2 \mathrm{ml}$ of aqueous extract and shaken. Concentrated $\mathrm{H}_{2} \mathrm{SO}_{4}$ was added on the side of the test tube. The presence of violet ring at the junction of two liquids indicated the presence of carbohydrates.

Tests for steroids: The Lieberman-Burchard Reaction was used for identification of steroids. A mixture of $2 \mathrm{ml}$ of extract, $2 \mathrm{ml}$ of chloroform and $2 \mathrm{ml}$ of acetic anhydride was made. Then 2 drops of concentrated $\mathrm{H}_{2} \mathrm{SO}_{4}$ were added from the side of test tube. It was observed for first red, then blue and finally green colour.

Test for alkaloids: To $3 \mathrm{ml}$ of methanolic extract, few drops of Dragendorf's reagents were added and the mixture was observed for orange brown precipitate.

Test for Glycoside: The test was divided into two parts and both observations were compared for final conclusion.

Part A: To $3 \mathrm{ml}$ of extract, diluted $\mathrm{H}_{2} \mathrm{SO}_{4}$ was added and heated on a water bath for 2 min, and then the mixture was neutralized with $1 \mathrm{~N} \mathrm{NaOH}$ solution. The $\mathrm{pH}$ was checked with litmus paper and to resulting solution was added Fehling's A and B. Intense red precipitate indicated that glycosides might be present.

Part B: To $3 \mathrm{ml}$ of extract, distilled water was added and heated. According to part A where $\mathrm{NaOH}$ was added for neutralization, an equal quantity of water was added. Then to resulting solution was added Fehling's A and B. Increased red precipitate indicated the absence of glycoside.

Test for saponin: To $3 \mathrm{ml}$ of distilled water was dissolved $0.5 \mathrm{~g}$ of extract and the mixture was shaken vigorously for 1 min. Persistent foam indicated the presence of saponins.

Tests for coumarins: To $2 \mathrm{ml}$ of extract was added $1 \mathrm{ml}$ of $10 \%$ ammonia solution $\left(\mathrm{NH}_{4} \mathrm{OH}\right)$. One drop was spotted on filter paper and observed in UV chamber for the presence of blue or green fluorescence.

\section{Quantitative tests}

Estimation of total phenol content: The content in phenolic constituents of the extracts was estimated by using FolinCiocalteu (FC) method [24], based on the oxidation of phenolic group with phosphotungstic acid to yield a green-blue complex.

The extracts and standard, Gallic acid (10 mg each) were dissolved separately in $\mathrm{MeOH}$ and the volume was made up to $10 \mathrm{ml}$. These solutions were serially diluted with methanol to obtain the lower dilutions. In a test tube were added $1 \mathrm{ml}$ of FC reagent $(2 \mathrm{~N})$ diluted $(1: 10)$ of with distilled water, $0.8 \mathrm{ml}$ sodium carbonate $(0.7 \mathrm{M})$ and $0.2 \mathrm{ml}$ of diluted methanolic extract. After shaking, all tubes were kept for $2 \mathrm{~h}$ at room temperature to complete the reaction. The absorbance was measured at $750 \mathrm{~nm}$ using a UV/visible spectrophotometer. Standard curve prepared with Gallic acid give a linear correlation $\left(y=0.103 x, R^{2}=0.996\right)$ in the range $0.5-10 \mu \mathrm{g} / \mathrm{ml}$. The phenolic content of extract was computed and the values were expressed in Gallic acid equivalent $\mathrm{mg} / \mathrm{g}$ of the dried extract.

\section{Estimation of total flavonoids}

Flavonoid contents of extracts were determined by a modified colorimetric method described by Lin and Lee [25]. To 400 $\mu \mathrm{l}$ of distilled water was added $20 \mu \mathrm{l}$ of extract, $50 \mu \mathrm{l}$ of a $7.5 \%$ sodium nitrite solution and $20 \mu \mathrm{l}$ of $15 \%$ aluminum chloride solution. After $6 \mathrm{~min}$ incubation, $200 \mu \mathrm{l}$ of $1 \mathrm{M}$ sodium hydroxide and $1 \mathrm{ml}$ of distilled water were added to the mixture and the absorbance was read at $510 \mathrm{~nm}$. Quercetin was used for as standard and from the calibration curve, the flavonoids content of different extracts were computed and expressed as quercetin equivalent in $\mathrm{mg} / \mathrm{g}$ of dried extract.

\section{Estimation of total antioxidant activity}

The total antioxidant activity of extract was evaluated by phosphomolybdenum method [26].

The mixture of $1 \mathrm{ml}$ of the reagent ( $4 \mathrm{mM}$ ammonium molybdate, $0.6 \mathrm{M}$ sulfuric acid and $28 \mathrm{mM}$ sodium phosphate) and $200 \mu \mathrm{l}$ of diluted extract in $\mathrm{MeOH}$ was sealed in an Eppendorf tube and boiled at $95^{\circ} \mathrm{C}$ for 90 min. The optical density was read at $695 \mathrm{~nm}$ using a UV/visible spectrophotometer. Ascorbic acid was used as standard and from the calibration curve $\left(y=0.0043 x, R^{2}=0.9984\right)$ with linear correlation within 25 and $200 \mu \mathrm{g} / \mathrm{ml}$; the total antioxidant of different extracts was determined and expressed in equivalent ascorbic acid in $\mathrm{mg} / \mathrm{g}$ of dried extract. 


\section{Estimation of total reducing power}

The reducing power was estimated by the method of Chou et al. [27]. In a test tube was added $2.5 \mathrm{ml}$ of phosphate buffer $(200 \mathrm{mM}, \mathrm{pH} 6.6), 2.5 \mathrm{ml}$ of $1 \%$ potassium ferricyanide and $1 \mathrm{ml}$ of diluted extract. All test tubes were incubated at $50 \circ \mathrm{C}$ for $20 \mathrm{~min}$ and $2.5 \mathrm{ml}$ of $10 \%$ trichloro acetic acid (TCA) was added. They were further kept for $30 \mathrm{~min}$, and then centrifuged for $10 \mathrm{~min}$ at $3000 \mathrm{rpm}$. The upper layer of solution $(2.5 \mathrm{ml})$ was mixed with distilled water $(2.5 \mathrm{ml})$ and $\mathrm{FeCl}$ $(1 \mathrm{ml}, 0.1 \%)$ and incubated for $5 \mathrm{~min}$. The absorbance was measured at $700 \mathrm{~nm}$ against a blank using UV/Visible spectrophotometer. The calibration curve was obtained with ascorbic acid with linear correlation $\left(y=0.0043 x, R^{2}=\right.$ 0.9984) between 25 and $200 \mu \mathrm{g} / \mathrm{ml}$, and the reducing power of the extract was computed and expressed in equivalent ascorbic acid in $\mathrm{mg} / \mathrm{g}$ of dried extract.

\section{Evaluation of antiradical activity of plant extracts by scavenging systems}

All extracts were screened for their antioxidant activity by determining their minimum concentration required to scavenge half $(50 \%)$ of a fixed amount of each specific radical $\left(\mathrm{IC}_{50}\right)$ present in the medium. All experiments were designed as follow:

- Assay control which contained reagent and solvent (in which the extract is diluted) without extract;

- Sample which contain extract (at a defined concentration) and reagent;

- Sample control which contain extract and solvent (in which the radical reagent is dissolved) without reagent.

The test absorbance was computed as Absorbance sample - Absorbance sample control. The percentage of scavenging or percentage of inhibition (\%l) was computed using the formula below.

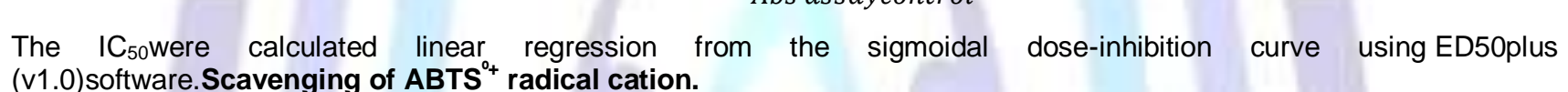

All extracts were screened for their scavenging activity against $\mathrm{ABTS}^{\circ+}$ radical cation by the method described by $\mathrm{Re}$ et al., [28].

In a flask were mixed $0.3 \mathrm{ml}$ of $17 \mathrm{mM}$ Potassium persulfate and $50 \mathrm{ml}$ of $2 \mathrm{mM}$ ABTS solution. The flask was cover with aluminum foil and kept overnight in dark till a green colour was developed. The absorbance was read at $734 \mathrm{~nm}$ and adjusted to 0.7 (working reagent) by diluting the solution with distilled water. In a test tube were added $1 \mathrm{ml}$ of $\mathrm{MeOH}, 0.2$ $\mathrm{ml}$ of diluted extract in $\mathrm{MeOH}$ and $0.16 \mathrm{ml}$ of working reagent. The mixture was incubated for 20 min at room temperature. Absorbance was measured at $734 \mathrm{~nm}$ using a UV-visible spectrophotometer. Ascorbic acid was used as standard.

\section{Scavenging of DPPH radical}

This essay was carried out in a 96-well microtiter plate as done by many authors [29].

In each well were added $200 \mu \mathrm{l}$ of freshly prepared $100 \mu \mathrm{M}$ DPPH and $10 \mu \mathrm{l}$ of diluted extract in MeOH. The plates were incubated at $37^{\circ} \mathrm{C}$ for $30 \mathrm{~min}$ and the absorbance was read at $490 \mathrm{~nm}$ using an ELISA reader. Ascorbic acid was used as standard.

\section{Scavenging of hydrogen peroxide}

Scavenging hydrogen peroxides by plant extracts was evaluated [30].

Various concentrations of the samples (extracts and standard) in methanol $(1 \mathrm{ml})$ were added to $2 \mathrm{~mL}$ of hydrogen peroxide solution in phosphate buffer saline (PBS, pH 7.4). After 10 min incubation, the absorbance was measured at 230 $\mathrm{nm}$ with a UV-visible spectrophotometer. Ascorbic acid was used as standard.

\section{Anti-lipoperoxidation activity}

The protective effect of extract against lipid peroxidation was evaluated on rat brain homogenates. Prior to this experiment we earlier obtained an Ethical clearance for animal experimentation

from the Institutional Animal Ethical Committee of SreeSiddganga College of Pharmacy, Tumkur, Karnataka, India (Ref:SSCPT/IAEC.Clear/141/2012-13) and the Faculty of Health Sciences Institutional Review Board (Ref. No.: 2011/058/UB/.FHS/IRB) at the University of Buea, Cameroon. To prepare the homogenates a total of 6 overnight fasted albinos rats $(150-200 \mathrm{~g})$ were sacrificed. The brains were removed, washed with ice cold saline and homogenized in 10 volumes of ice cold PBS ( $\mathrm{pH}$ 7.4) using a glass homogenizer. The homogenates were cold (4을 centrifuged at $1000 \mathrm{rpm}$ for $10 \mathrm{~min}$. A stock solution of $10 \mathrm{mg} / \mathrm{ml}$ of extract was prepared in $\mathrm{MeOH}$, and the lower concentrations were obtained by dilution. Tocopherol was diluted in $\mathrm{MeOH}$ and used as standard. To $0.25 \mathrm{ml}$ of homogenate was added $0.25 \mathrm{ml}$ of sample and the lipid peroxidation was initiated by adding $0.25 \mathrm{ml}$ of $\mathrm{FeCl} 3(100 \mu \mathrm{M})$ and $0.25 \mathrm{ml}$ of ascorbic acid (100 $\mu \mathrm{M})$, followed by incubation at $37^{\circ} \mathrm{C}$ for 20 min. The reaction was stopped by adding $1 \mathrm{~mL}$ of $0.25 \mathrm{~N} \mathrm{HCl}$ containing $15 \%$ trichloro acetic acid $0.375 \%$ thiobarbituric acid and $0.05 \%$ butylatedhydroxytoluene (BHT). The mixture was boiled for 15 min then cooled, centrifuged at $3000 \mathrm{rpm}$ for $5 \mathrm{~min}$ and the absorbance of the supernatant was measured at $532 \mathrm{~nm}$. 


\section{Nitric oxide radical inhibition assay}

Scavenging nitrite oxide radical of extract was done using modified previously described method [31]. The reaction mixture $(6 \mathrm{~mL})$ containing sodium nitroprusside $(10 \mathrm{mM}, 4 \mathrm{~mL})$, phosphate buffer saline $(1 \mathrm{~mL})$ and the extracts, the compound and standard solutions $(1 \mathrm{~mL})$ were incubated at $25^{\circ} \mathrm{C}$ for $150 \mathrm{~min}$. After incubation, $0.5 \mathrm{~mL}$ of the reaction mixture was removed and mixed to $1 \mathrm{~mL}$ of sulphanilic acid reagent $(0.33 \%$ in $20 \%$ glacial acetic acid) and allowed to stand for 5 min for completion of diazotization reaction and then $1 \mathrm{~mL}$ of NEDD was added, mixed and allowed to stand for another $30 \mathrm{~min}$ in diffused light. The absorbance was measured at $540 \mathrm{~nm}$ against the corresponding blank solutions in a 96-well microplate titre using ELISA reader (Epoch, USA).

\section{Scavenging hydroxyl radical}

Scavenging activity of extracts on hydroxyl radical was achieved using the deoxiribose method [32]. In a test tube was added $1 \mathrm{ml}$ of phosphate buffer, $0.3 \mathrm{ml}$ of $1 \mathrm{mM} \mathrm{FeCl} 3$ and $0.3 \mathrm{ml}$ of $1 \mathrm{mM}$ EDTA. After 2 min pre-incubation was added 0.3 $\mathrm{ml}$ of sample, $0.3 \mathrm{ml}$ of $20 \mathrm{mM}$ hydrogen peroxide in phosphate buffer $(\mathrm{pH}, 7.4,20 \mathrm{mM}), 0.3 \mathrm{ml}$ of $1 \mathrm{mM}$ ascorbic acid and $0.3 \mathrm{ml}$ of $30 \mathrm{mMDeoxyribose.} \mathrm{The} \mathrm{reaction} \mathrm{mixture} \mathrm{was} \mathrm{further} \mathrm{incubated} \mathrm{for} 30 \mathrm{~min}$ at $37^{\circ} \mathrm{C}$. Then, $1 \mathrm{ml}$ of ice-cold mixture containing $2.8 \%$ trichloro-acetic acid and $0.5 \%$ thiobarbituric acid in $0.25 \mathrm{~N} \mathrm{HCl}$ were added. The reaction mixture was kept in a boiling water bath for $30 \mathrm{~min}$, cooled and the absorbance was measured at $532 \mathrm{~nm}$.

\section{Scavenging superoxide radical}

Superoxide radical anion scavenging activity was evaluated using PMS-NADH system by modified method of [33].

In each well of 96 -well microtiter plate were added $50 \mu \mathrm{l}$ of $312 \mu \mathrm{M} \mathrm{NBT}, 50 \mu \mathrm{l}$ of $936 \mu \mathrm{M}$ NADH and $50 \mu \mathrm{l}$ of sample. The reaction was initiated by adding $5 \mu \mathrm{l}$ of $120 \mu \mathrm{M}$ PMS. All reagents were prepared in $100 \mathrm{mM}$ phosphate buffer $\mathrm{pH} 7.4$. The reaction mixture was incubated for $5 \mathrm{~min}$ at $25^{\circ} \mathrm{C}$ and the absorbance was read at $560 \mathrm{~nm}$ using ELISA reader plate.

\section{Statistical analysis}

All experiments were run in triplicate and the results were expressed as mean \pm standard deviation. Correlation analyses of antioxidant activity versus the total phenolic and flavonoid content were performed using Pearson's correlation in SPSS 17.0. Data were subjected to analysis of variance followed by Tukey's Post-test. The $p$ value less than 0.05 was considered to be statistically significant.

\section{RESULTS}

\section{Phytochemical screening}

All extracts were screened qualitatively for major classes of phytochemical compounds and results are summarized in table 2. The main phytochemical classes targeted were phenolic and flavonoids because these compounds have been reported as potent antioxidants. They were quantified in extracts simultaneously with their total antioxidant activities and reducing powers.

Table2: Results of phytochemical screening for different plant extracts

\begin{tabular}{|l|l|l|l|l|l|l|}
\hline \multirow{2}{*}{ Extracts } & \multicolumn{5}{|c|}{ Phytochemical tests } \\
\cline { 2 - 7 } & Glycosides & Steroids & Saponins & Alkaloids & Carbohydrates & Coumarins \\
\hline AC & + & - & + & + & + & - \\
\hline BA & - & & & & & \\
\hline CF & - & + & - & + & + & + \\
\hline CuA & + & - & - & + & - & + \\
\hline CyA & + & - & + & + & + & - \\
\hline DL & + & - & + & - & + & + \\
\hline LS & + & - & - & - & + & + \\
\hline NP & + & + & + & + & + & - \\
\hline PA & - & + & - & - & + & + \\
\hline PN & - & + & - & + & + & + \\
\hline $\begin{array}{l}\text { Autranellacongolensis; BA: Beilschmiediaanacardioides; CF: Crossopteryxfebrifiga; Cu A: Cussoniaarborea; } \\
\text { Cy A: Cyphostema adenaucaule; } \\
\text { Naucleapobeguinii; PA: Pycnanthusangolensis; PN: Picralimanitida }\end{array}$ \\
\hline
\end{tabular}


The total amount of phenol constituents of different extracts were determined and expressed as Gallic acid (GA) equivalent (mg/g of extract), and it was found that, the amount of phenolic content differed from one plant to another as illustrated in figure 1a.The significantly highest $(P<0.05)$ phenolic content was obtained with $A C$ methanolic's extract $(450 \pm 7.37$ equivalent GA mg/g of extract) while the highest flavonoid content was found in NP and AC with values of $144.85 \pm 5.16$ and $152.15 \pm 4.15 \mathrm{mg}$ equivalent ascorbic acid $/ \mathrm{g}$ of crude extract respectively. Significant positive correlations were observed between total antioxidant activity with total reducing power $\left(p<0.01 ; R^{2}=0.8190\right)$, total flavonoids $\left(P<0.05 ; R^{2}=0.6419\right)$ and total phenol $\left(P<0.01 ; R^{2}=0.8643\right)$.

\section{Antioxidant activity of extracts by scavenging systems}

These tests were performed by determining the scavenging activity of the extracts against free radicals. Hence we evaluated the $\mathrm{IC}_{50}$ for scavenging activity of all extracts against $\mathrm{DPPH}, \mathrm{ABTS}$, superoxide, hydroxyl and nitric oxide radicals, then hydrogen peroxide and lipid peroxidation. On the basis of the results obtained above, all extracts exhibited dose dependent inhibition of $\mathrm{ABTS}^{\circ+}$, DPPH and hydroxyl radicals. They were also able to prevent lipid peroxidation. The methanolic extracts of CF, DL, LS and AC showed high antioxidant activities and scavenged all radicals tested, while PN, $\mathrm{BA}, \mathrm{CyA}$ and PA extracts were inactive against hydrogen peroxide, hydroxyl radical and the superoxide radical. The most potent antioxidant activity was obtained with AC extract, which showed lowest significant values $(p<0.05)$ of $I C_{50}$ as compared to the standards. The $\mathrm{IC}_{50}$ values of this extract were $7.31 \pm 0.25,5.20 \pm 0.35,42.17 \pm 0.60,77.30 \pm 7.41$, $32.94 \pm 1.32,9.71 \pm 1.07$ and $121.59 \pm 1.08 \mu \mathrm{g} / \mathrm{ml}$ against ABTS, DPPH, hydrogen peroxide, inhibition of lipid peroxidation, superoxide radical, hydroxyl radical and nitric oxide radical respectively (Table 3 ).

Table 3: IC50 values of plant extracts against free radical tested $(\mu \mathrm{g} / \mathrm{ml})$.

\begin{tabular}{|c|c|c|c|c|c|c|c|}
\hline \multirow{2}{*}{$\begin{array}{l}\text { Plant extracts } \\
\text { and standards }\end{array}$} & \multicolumn{7}{|c|}{ Antioxidant tests performed } \\
\hline & $\begin{array}{l}\text { ABTS } \\
\text { scavenging }\end{array}$ & $\begin{array}{l}\text { DPPH } \\
\text { scavenging }\end{array}$ & $\begin{array}{l}\text { Hydrogen } \\
\text { peroxide } \\
\text { scavenging }\end{array}$ & $\begin{array}{l}\text { Lipid } \\
\text { peroxidation }\end{array}$ & $\begin{array}{l}\text { Superoxide } \\
\text { radical } \\
\text { scavenging }\end{array}$ & $\begin{array}{l}\text { Hydroxyl } \\
\text { radical }\end{array}$ & $\begin{array}{l}\text { Nitric oxide } \\
\text { radical }\end{array}$ \\
\hline AC & $7.31 \pm 0.25$ & $5.20 \pm 0.35$ & $42.17 \pm 0.60$ & $77.30 \pm 7.41$ & $32.94 \pm 1.32$ & \begin{tabular}{|l|l|}
$9.71 \pm 1.07$ \\
\end{tabular} & $121.59 \pm 1.08$ \\
\hline$\overline{B A}$ & $28.20 \pm 0.44$ & $74.07 \pm 1.72$ & - & $116.84 \pm 12.24$ & - & $255.06 \pm 9.62$ & - \\
\hline CF & $22.23 \pm 0.12$ & $15.67 \pm 1.44$ & $179.00 \pm 0.58$ & $198.25 \pm 11.42$ & $92.61 \pm 1.16$ & $70.83 \pm 0.84$ & $315.14 \pm 1.68$ \\
\hline Cu A & $25.50 \pm 0.68$ & $91.93 \pm 3.10$ & & $172.41 \pm 6.98$ & $462.69 \pm 9.44$ & $100.89 \pm 0.62$ & $511.83 \pm 4.13$ \\
\hline Су A & $26.77 \pm 0.78$ & $98.17 \pm 2.89$ & - & $886.77 \pm 14.02$ & - & $122.02 \pm 1.40$ & - \\
\hline DL & $17.93 \pm 0.12$ & $7.73 \pm 0.35$ & $198.67 \pm 0.88$ & $262.52 \pm 3.66$ & $38.72 \pm 2.84$ & $58.50 \pm 1.96$ & $433.95 \pm 6.37$ \\
\hline LS & $13.17 \pm 0.42$ & $29.67 \pm 2.24$ & $136.33 \pm 1.20$ & $226.48 \pm 10.28$ & $101.81 \pm 1.66$ & $54.91 \pm 1.90$ & $337.28 \pm 1.43$ \\
\hline NP & $28.27 \pm 0.47$ & $51.00 \pm 1.55$ & $131.00 \pm 0.58$ & $260.29 \pm 5.64$ & - & $35.53 \pm 0.37$ & $288.34 \pm 0.08$ \\
\hline$\overline{\mathbf{P A}}$ & $38.13 \pm 0.88$ & $65.27 \pm 9.41$ & - & $161.12 \pm 4.21$ & - & $278.09 \pm 10.35$ & - \\
\hline $\mathbf{P N}$ & $29.27 \pm 0.19$ & $85.17 \pm 2.89$ & - & $428.83 \pm 8.36$ & - & $159.85 \pm 10.24$ & - \\
\hline Ascorbic acid ${ }^{*}$ & $6.92 \pm 0.07$ & $3.60 \pm 0.23$ & $123.00 \pm 2.65$ & & $98.68 \pm 4.44$ & $49.78 \pm 5.65$ & $117.24 \pm 0.74$ \\
\hline a-tocopherol* $^{*}$ & - & - & & $90.35 \pm 4.65$ & - & & - \\
\hline \multicolumn{8}{|l|}{$-:$ not determined } \\
\hline \multicolumn{8}{|l|}{ *standard molecule } \\
\hline \multicolumn{8}{|c|}{ Values are mean \pm standard error of mean. } \\
\hline \multicolumn{8}{|c|}{ The lower the IC50 value, the higher the antioxidant activity } \\
\hline
\end{tabular}

Autranellacongolensis; BA: Beilschmiediaanacardioides; CF: Crossopteryxfebrifiga; Cu A: Cussoniaarborea; Cy A: Cyphostema adenaucaule; DL: Dissotislongipetala; LS: Lonchocarpussepium; NP: Naucleapobeguinii; PA: Pycnanthusangolensis; PN: Picralimanitida

Negative significant correlations (table 4) were obtained between the $\mathrm{IC}_{50}$ of all scavenging systems tested and the total phenol content of the extracts. Marked negative correlations $(P<0.05)$ were also observed between ABTS, DPPH, superoxide, hydroxyl and nitric oxide radicals' assays with the total antioxidant activity and the total reducing powers. 
Table 4: Correlations between the $\mathrm{IC}_{50}$ of various scavenging systems and the quantification systems

\begin{tabular}{|c|c|c|c|c|}
\hline Systems & Total Phenol & $\begin{array}{l}\text { Total antioxidant } \\
\text { activity }\end{array}$ & $\begin{array}{l}\text { Total } \\
\text { Flavonoids }\end{array}$ & $\begin{array}{l}\text { Total reducing } \\
\text { power }\end{array}$ \\
\hline ABTS & $-0,83562^{\star \star}$ & $-0,86662^{\star \star}$ & $-0,25865$ & $-0,80448^{\star \star}$ \\
\hline DPPH & $-0,74263^{\star *}$ & $-0,75048^{\star \star}$ & $-0,33214$ & $-0,8417^{\star \star}$ \\
\hline Hydrogen peroxide & $-0,69477^{\star *}$ & $-0,55338^{*}$ & $-0,55492$ & $-0,56711^{*}$ \\
\hline Hydroxyl radical & $-0,65817^{* *}$ & $-0,8244^{\star *}$ & $-0,37648$ & $-0,66075^{\star}$ \\
\hline Lipid peroxidation & $-0,38589^{* *}$ & $-0,14843$ & $-0,34272$ & $-0,43976$ \\
\hline Nitric oxide radical & $-0,87665^{* *}$ & $-0,81035^{\star \star}$ & $-0,65461$ & $-0,63045^{\star}$ \\
\hline Superoxide radical & $-0,64351^{*}$ & $-0,79903^{\star *}$ & $-0,36334$ & $-0,79399^{\star *}$ \\
\hline $\begin{array}{l}{ }^{\star *} \text { : Correlation is sig } \\
{ }^{*} \text { : Correlation is sign }\end{array}$ & $\begin{array}{l}\text { at } p<0.01 \text { leve } \\
\text { at } p<0.05 \text { level }\end{array}$ & & & \\
\hline
\end{tabular}

\section{DISCUSSION}

Plants contain a wide variety of free radical scavenging molecules, such as flavonoids, anthocyanins, carotenoids, dietary glutathionine, alkaloids, tannins, saponins, steroids, terpenoids and rotenoids which are rich in antioxidant activities [6]. ROS produced in vivo include superoxide radical $\left(\mathrm{O}_{2}^{*}\right)$, hydrogen peroxide $\left(\mathrm{H}_{2} \mathrm{O}_{2}\right)$ and hypochlorous acid $(\mathrm{HOCl})$ can interact in the presence of certain transition metals to yield highly-reactive oxidizing species, the hydroxyl radical $\left(\mathrm{HO}^{*}\right)$ [34]. Consequently, an adequate intake of polyphenols diet can help to prevent the oxidative stress generated when the production of ROS is beyond the antioxidant capacity of a biological system [35, 36]. Quantitative analyses showed that Autranellacongolensis' content in total flavonoids, total phenolic compounds, total antioxidant and total reducing power was important compare to other extracts (figure 1).

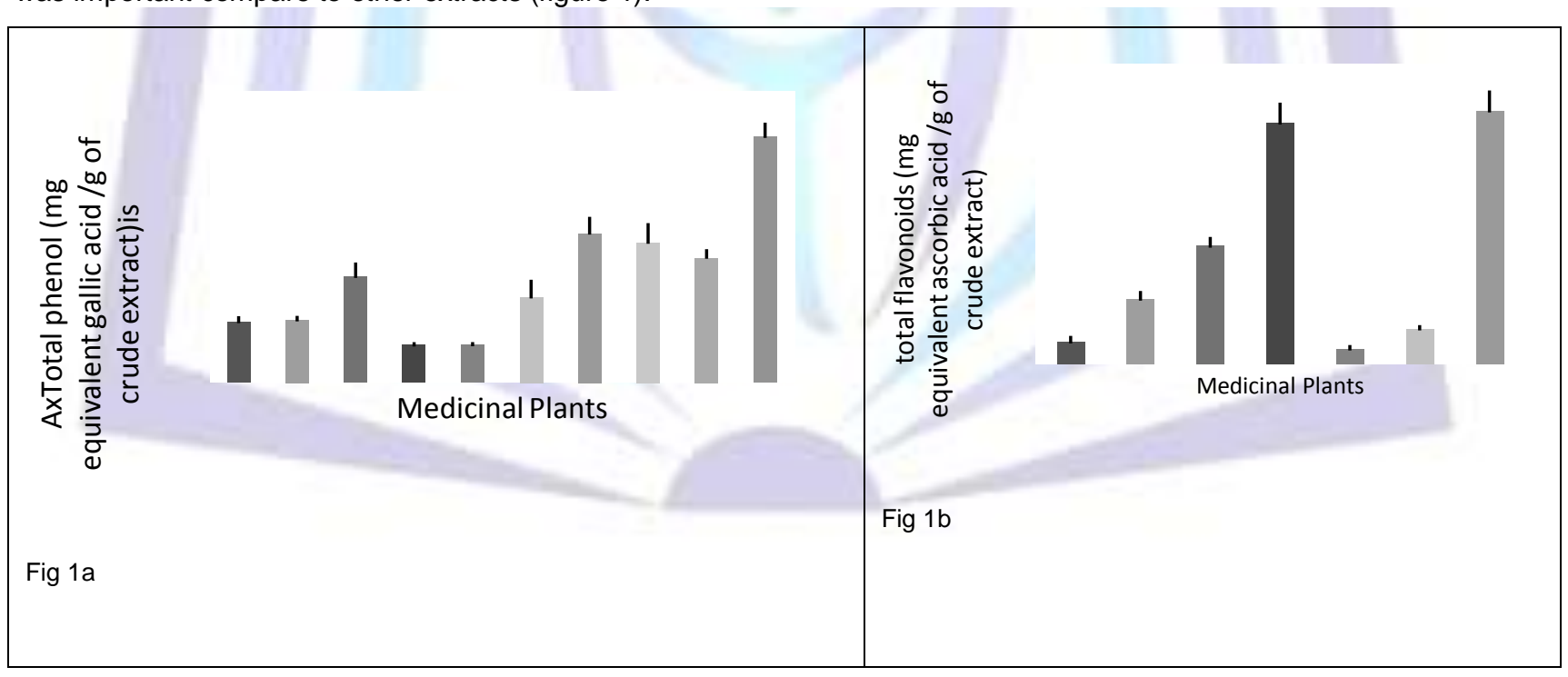




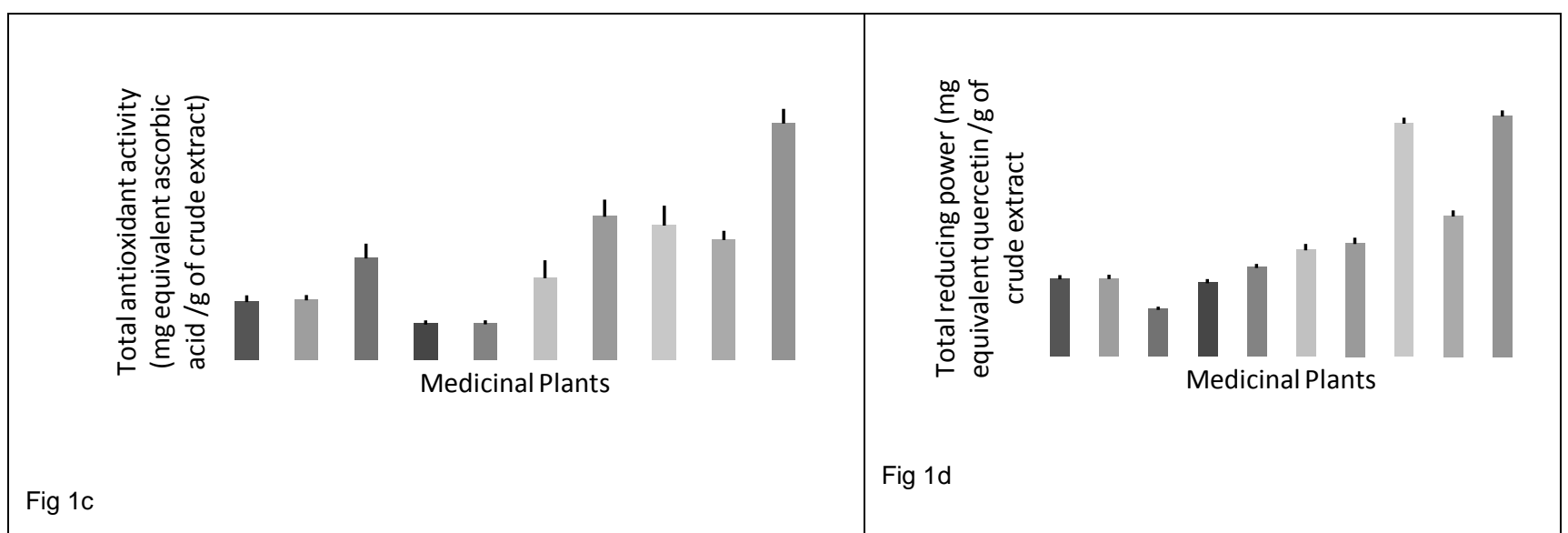

Figure 1: Quantitative analysis of crude extracts. 1a: Total phenol (mg equivalent gallic acid /g of crude extract); 1b: total flavonoids (mg equivalent ascorbic acid /g of crude extract); 1c: Total antioxidant activity (mg equivalent ascorbic acid /g of crude extract); $1 \mathrm{~d}$ : Total reducing power (mg equivalent quercetin /g of crude extract.

Ethnobotanical investigations have earlier shown its importance in the treatment of diarrhoea and chronic dysentery [9]. Previous Chemical investigations of $A$. congolensis led to the isolation of six compounds of which three were pentacylictriterpenes of the taraxerane type, together with one $\Delta 7$-sterol (24R)-stigmast-7,22(E)-dien-3 $\alpha$-ol (chondrillasterol), and two phenolic compounds (+)- catechin and 24-feruloytetracosanoic acid [9]. The use of this plant as antiinflamatory agent could thus be linked to (+)-catechin[9]. Flavonoids reduce free radicals by quenching, up-regulating or protecting antioxidant defenses and chelating radical intermediate compounds. Alkaloids and their synthetic derivatives from this plant possess analgesic activities when administered to animals [37]. A lower $\mathrm{IC}_{50}$ value corresponds to a larger scavenging power and a DPPH radical scavenging activity of less than $50 \mu \mathrm{g} / \mathrm{ml}$ is considered significant [38]. Based on $\mathrm{IC}_{50}$ values, results presented in table 3 show that the methanolic extract of Autranellacongolensis is comparable to standard drugs ascorbic acid and alpha tocopherol and deployed the highest antiradical activity among the extracts tested. This important antiradical activity may be due to its important content in total phenol content, given that a strong negative correlation exists between total phenol content and the $\mathrm{IC}_{50}$ of various scavenging systems (table 4). The use of $\mathrm{AC}$ in treating different ailments associated with oxidative stress like Diarrhea and chronic dysentery, malaria [8,9] is hereby justified. The potentials of this plant's extract as a source of natural antioxidants in many devastating diseases like AIDS and hepatitis should be envisaged [37]. B. anacardioides(BA) stem bark is used in the Noun sub-division of the West Region of Cameroon to treat uterine tumours, rubella, rheumatisms, bacterial and fungal infections [10] whereas seeds are used as spices. Another species $B$. lancilimba is used in the same region to cure skin bacterial infections whereas $B$. manii is used to treat dysentery and headache and as an appetite stimulant [10,39]. Its phytochemistry revealed the presence of flavonoids and phenols (figure 1) which can justify its antioxidant, antiradical and reductive properties. Although its total phenol and flavonoids content appears to be lower compared to that of other extracts, its total reducing power is considerable (figure1). BA however presented $\mathrm{IC}_{50}$ values indicating significant antiradical properties on some radical systems notably the DPPH $(28.20 \pm 0.44)$ and ABTS $(74.07 \pm 1.72)$ systems. The lack of action on other systems like hydrogen peroxide, hydroxyl radical and the superoxide radical may be due to the nature of their phenol compounds. Other studies have shown that phenolic compounds isolated from Beilschmiedia species like Vanillin and 4hydroxybenzaldehyde were analgesic, anti-inflammatory and antifungal [10]. Endiandric acid $\mathrm{H}$ used to manufacture drugs for treatment of asthmatic disorders or concomitant inflammatory symptoms was isolated from this species. Traditional preparations of Crossopteryxfebrifuga (Afzel.) Benth. (CF) (Rubiaceae) are widely used in Northern Nigeria in the management of trypanosomiasis, malaria and painful inflammatory disorders [11]. Previous studies have shown that the methanolic extract of the stem bark of CF possesses significant analgesic and anti-inflammatory properties possibly mediated via Non-selective inhibition of cyclo-oxygenase pathways. A recently discovered property as cytoprotective effect on the gastrointestinal tract (GIT) [11] and as antimalarial [12] may be due to its important content in phenolic, flavonoids and tannins (figure 1). Its significant antiradical and antioxidant activity on the DPPH and ATBS systems with IC 50 less than $50 \mu \mathrm{g} / \mathrm{ml}$ indicates a source of potent interesting drugs against infectious diseases and debilitating effects due to opportunistic infections always associated to immunosuppressive diseases and inflammation conditions. Cussonia species are used in African traditional medicine mainly against pain, inflammation, gastro-intestinal problems, malaria and sexually transmitted diseases [40]. An average total antioxidant activity and total reducing power of Cussoniaaboriawas obtained in this study. The antioxidant property of Cyphostema adenaucaule (Orchidaceae) is presented for the first time in this work. Dissotislongipetala (DL) presented a phytovchemical profile made up of glycosides, carbohydrates, phenols, tannins and coumarins. Its bark extract indicated high total phenol and low total flavonoids contents (figure 1) with very important antioxidant and reducing power. It can be postulated that these antioxidant and reducing power are due to its important phenolic content. $\mathrm{IC}_{50} \leq 50 \mu \mathrm{g} / \mathrm{ml}$ were obtain against 3 of the 6 antiradical systems notably ABTS, DPPH, and superoxide radicals. For the best of our knowledge antioxidant and reducing powerproperties are revealed here for the first time. Although the total flavonoids of Lonchocarpussepium content was poor (figure 1b), the extract was rich in total phenol which correlated well with its antioxidant and reductive power (figure 1a, 1c, 1d). The antiradical power of the extract was interesting on the ABTS, DPPH, and the hydroxyl radical systems. This evaluation on Lonchocarpussepium appears to be the first of its kind on the antiradical activity of this species. Naucleapaubeguiniis a Rubiaceaand many pharmacological 
studies have been reported on some family members like Nauclealafolia indicated the presence of flavonoids, phenols, tannins and alkaloids with anticancer and anti-inflammatory properties [41]. We detected in the methanolic extract of Naucleapaubeguinithe presence of these same phyto-constituents with strong antioxidant activity and reduction power correlating with its phenol and flavonoids contents. The extract was also very efficient on many antiradical systems like the ABTS, DPPH and hydroxyl radical with $\mathrm{IC}_{50}$ close to $50 \mu \mathrm{g} / \mathrm{ml}$. Pycnanthusangolensis, a Myristicaceae is used against bile \& liver complaints, stomachache, hypercholesterolemia, type 2 diabetes and cancer [17]. Its leaves' methanolic extract have been proven to possess anti- helminthic and antimicrobial properties [42].Allantoin, isoflavonoids and dihydroguaiacetic acid have been isolated from the bark while some terpenoidquinones with hypoglycaemic activity have been found in the bark and leaves [42]. Picralimanitida seeds' extract has been studied before; it possesses antiinflammatory and analgesic properties. The extract in addition to its known opioid analgesic actions also has antagonistic actions on bradykinin-induced hyperalgesia. The extract also induces rat cytochrome P450 enzymes [43]. This is in accordance with our study showing an important antioxidant activity and reductive power. Mabekuet al. [44] detected the presence of Alkaloids, flavonoids, saponins, polyphenols in the methanolic extract of PN and described its antimicrobial properties. In general ethnobotanical investigations reported that medicinal plants studied are used for the treatment of various diseases associated with oxidative stress. The therapeutic benefit of these plants may be due to their antioxidant properties which were explored using different free-radical generating systems. A wide range of works have been done in this field to sustain the protective effect of dietary phenols in the protection against degenerative diseases [45-53]. Selective scavenging activities of AC, CF, CUA, DL and LS extracts were observed against superoxide anion. The reported activity is the scientific basis of the protective effect of these plants against oxidative damage. Because all the extracts deployed significant antioxidant activity, their protective activity on DNA strand scission is to be explored. The protective effect of the extracts on lipid peroxidation was shown in our studies. Lipid peroxidation generally initiated by prooxidant species is a common mechanism of tissue necrosis during oxidative damage [54, 55].

These results suggest that selected plants can be used as a source of antioxidants for pharmacological preparations. The ability of these extracts to quench free radicals using in vivo oxidative stress models is to be envisaged.

\section{AUTHOR'S CONTRIBUTIONS}

AJN designed the protocol, executed the laboratory work and drafted the manuscript. PEAN contributed to ethnobotanical survey, provided the plant and contributed to draft the manuscript.JRC prepared the extracts, while JCAN contributed to ethnobotanical survey and to design the protocol, read and substantially revised the manuscript. SW contributed to the protocol designing and revised the manuscript. SMB, VVV and BDT contributed to monitor the laboratory work and provided required chemicals and laboratory consumables for different analysis. All authors read and approved the manuscript.

\section{ACKNOWLEDGMENTS}

The authors thank the Centre of International Co-operation in Sciences (CICS), Chennai, India, to provide Research Training Fellowship for developing Country Scientists (RTFDCS) to one of the authors (AJN). They also thank the Research laboratory of the Sri Siddaganga College of Pharmacy, Tumkur, Karnataka, India for providing research infrastructures, the International Foundation for Science (IFS) and the African Phytomedicine Center Alango Foundation, Dschang Cameroon for the partial financial support.

\section{COMPETING INTERESTS}

The author(s) declare that they have no competing interests.

\section{REFERENCES}

[1] Young, I. S., Woodside, J. V. 2001Antioxidants in health and disease. J ClinPathol, 54(3):176-186.

[2] Christen Y. 2000 Oxidative stress and Alzheimer disease. The American journal of clinical nutrition, 71(2):621S6295 .

[3] MacNee, W.2005 Pulmonary and systemic oxidant/antioxidant imbalance in chronic obstructive pulmonary disease. Proceedings of the American Thoracic Society. 2(1):50-60.

[4] Cai, H., Harrison, D. G.: Endothelial dysfunction in cardiovascular diseases: the role of oxidant stress. Circulation research 2000, 87(10):840-844.

[5] Squadriato, G. I., Pelor, W. A.2008 Free Radical Oxidative chemistry of nitric oxide: The roles of superoxide, peroxynitrite, and carbon dioxide. Free Radical Biology and Medicine 1998, 25:392-403.6.Pham-Huy LA, He H, Pham-Huy C: Free radicals, antioxidants in disease and health. International journal of biomedical science. 4(2):89-96.

[6] Assob, J. C, Nde, P. F., Nsagha, D. S., Njimoh, D. L., Nfor. O., Njunda, A. L., Kamga, H. L.2012The incidence of feco-oral parasites in street-food vendors in Buea, south-west region Cameroon. African health sciences. 12(3):376-380. 
[7] Musuyu M. D., Fruth B. I., Nzunzu, L. J., Mesia, G. K., Kambu, O. K., Tona, G. L., Cimanga, K. R., Cos, P., Maes, L., Apers, S. et al.2012In vitro antiprotozoal and cytotoxic activity of 33 ethonopharmacologically selected medicinal plants from Democratic Republic of Congo. Journal of ethnopharmacology. 141(1):301-308.

[8] Fokou, P. A. 2006Chemical Investigation of Three Plants Used in Cameroonian Traditional Medicine: Maesopsiseminii (Rhamnaceae), Autranellacongolensis (Sapotaceae) and Pentadesmagrandifolia (Guttiferae). Bielefeld, Germany: Bielefeld University.

[9] Nkeng-Efouet-Alango, P.2012Phytochemicals from Beilschmiediaanacardioides and Their Biological Significance. In: Phytochemicals - A Global Perspective of Their Role in Nutrition and Health. Edited by Rao DV: InTech;.

[10] Adeola, S. O., Yahaya, T. A., Hafsatu, B., Chinwe, N. A., Maryjane, E. C., Sunday, I., Adanna, N. M.2011Gastroprotective effect of Crossopteryxfebrifuga in Wistar rats. African journal of traditional, complementary, and alternative medicines: AJTCAM / African Networks on Ethnomedicines. 8(3):300-306.

[11] Elufioye, T. O., Agbedahunsi, J. M.2004 Antimalarial activities of Tithoniadiversifolia (Asteraceae) and Crossopteryxfebrifuga (Rubiaceae) on mice in vivo. Journal of ethnopharmacology 93(2-3):167-171.

[12] Kideghesho, J. R., Msuya, T. S.2010Gender and socio-economic factors influencing domestication of indigenous medicinal plants in the West Usambara Mountains, northern Tanzania. Ecosystem services and Management, 6(1-2):3-12.

[13] Bouare, A. S. 2004 Etude de la phytochimieet des activitésbiologiques des ecorces de racines de Cussoniabarteri. Bamako, Mali: Université du Mali..

[14] Ouologuem, T.2004 Etude de l'activitélarvicide de quelquesplantesmedicinales du Mali sur les larvesd'AnophelesgambiaessetCulexquinquefasciatus. These de Master. Bamako, Mali,:Université du Mali.

[15] Mahonge, C. P. I., Mtengeti, E. J., Mattee, A. Z.2006 Utilization of Medicinal Plants by Waluguru People in East Uluguru Mountains Tanzania African Journal of Traditional. African journal of traditional, complementary, and alternative medicines : AJTCAM / African Networks on Ethnomedicines 3(4):121-134

[16] Focho, D. A., Newu, M. C., Anjah, M., G., Nwana, F. A., Ambo,F. B.2009Ethnobotanical survey of trees in Fundong, Northwest Region, Cameroon. Journal of ethnobiology and ethnomedicine 5:17.

[17] Baerts, M., Lehmann, J.1989Guérisseursetplantesmédicinales de la région des crètesZaïre -Nil au Burundi . Tervuren, Belgique: Musée royal de l'Afriquecentrale.

[18] Stewart, J. L., Allison, G. E., Simons, A. J.1996. Gliricidiasepium. Genetic resources for farmers. In.; 125 pp.

[19] Pieters, L., Mesia, K., Tona, L., Mampunza, M., Ntamabyaliro, N., Muanda, T., Muyembe, T., Cimanga, K., Totté, J., Mets T. et al. 2011 A Phase IIA and IIB clinical trial of a quantified extract of Naucleapobeguinii stem bark against uncomplicated falciparum malaria. Plantamedica.77(12):SL65.

[20] Trease, G. E., Evans, W. C.: Pharmacognosy, 12 edn. London: BailliereTindall; 1983.

[21] Brunetton, J. 1999Pharmacognosy, Phytochemistry, Medicinal plants, 2 edn. Paris: Technique et documentation; 1999.

[22] Harborne JB: Phytochemical methods: a guide to modern techniques of plant analysis, 2 edn. London: Chapman and Hall; 1984.

[23] Sadasivam S, Manickam A: Biochemical Methods For Agricultural Sciences: New Age International Pub. (P) Limited; 1992.

[24] Lin, E. S., Lee, C. C. 2006 Evaluation of superoxide radical scavenging capacity and reducing power of areca flower extracts. Journal of Medicinal Plants Research, 4(10):975-981.

[25] Prieto, P., Pineda, M., Aguilar, M. 1999 Spectrophotometric quantitation of antioxidant capacity through the formation of a phosphomolybdenum complex: specific application to the determination of vitamin E. Analytical biochemistry. 269(2):337-341.

[26] Chou, Y. S., Ho Y. L., Ding, C. W., Chang, Y. S.2009New antioxidant phenylethanol glycosides from Toreniaconcolor. Journal of Asian natural products research 11(2):110-115.

[27] Re, R., Pellegrini, N., Proteggente, A., Pannala, A., Yang, M., Rice-Evans, C. 1999 Antioxidant activity applying an improved ABTS radical cationdecolorization assay. Free radical biology \& medicine. 26(9-10):1231-1237.

[28] Sreejayan, N., Rao, M. N. 1996 Free radical scavenging activity of curcuminoids. Arzneimittel-Forschung 46(2):169-171.

[29] Meena, H., Pandey, H. K., Pandey, P., Arya,M. C., Ahmed, Z.2012Evaluation of antioxidant activity of two important memory enhancing medicinal plants Baccopamonnieri and Centellaasiatica. Indian journal of pharmacology, 44(1):114-117. 
[30] Oyedemi, S. O., Afolayan,A. J.2011 Antibacterial and antioxidant activities of hydroalcoholic stem bark extract of SchotialatifoliaJacq. Asian Pacific journal of tropical medicine 4(12):952-958.

[31] Halliwell, B., Gutteridge, J. M., Aruoma,O. I. 1987 The deoxyribose method: a simple "test-tube" assay for determination of rate constants for reactions of hydroxyl radicals. Analytical biochemistry. 165(1):215-219.

[32] Nishimiki, M., Rao, N. A., Yagi, K.1972 The occurrence of superoxide anion in the reaction of reduced phenazinemethosulfate and molecular oxygen. Biochemical and Biophysical Research Communications. 46:849853.

[33] Aruoma, O. I., Halliwell, B., Laughton,M. J., Quinlan, G. J., Gutteridge, J. M.1989 The mechanism of initiation of lipid peroxidation. Evidence against a requirement for an iron(II)-iron(III) complex. The Biochemical journal. 258(2):617-620.

[34] Cos, P., Calomme, M., Sindambiwe, J. B., De Bruyne, T., Cimanga, K., Pieters, L., Vlietinck, A. J, VandenBerghe, D.2001 Cytotoxicity and lipid peroxidation-inhibiting activity of flavonoids. Plantamedica 67(6):515-519.

[35] Sies, H. 1993 Strategies of antioxidant defense. European journal of biochemistry / FEBS. 215(2):213-219.

[36] Otang, W. M., Grierson, DS, Ndip RN: Phytochemical studies and antioxidant activity of two South African medicinal plants traditionally used for the management of opportunistic fungal infections in HIV/AIDS patients. BMC complementary and alternative medicine 2012, 12:43.

[37] Erukainure, O. L., Oke, O. V., Owolabi, F. O., Kayode, F. O., Umanhonlen, E. E., Aliyu, M. 2012 Chemical properties of Monodoramyristica and its protective potentials against free radicals in vitro. Oxidants and Antioxidants in Medical Science. 1(2):127-132.

[38] Iwu, M. M., Handbook of African Medical plants. Boca Raton: CRC Press; 1993.

[39] De Villiers, B. J., Tilney, P. M., Van Wyk, E. B. 2010 The taxonomic significance of leaf anatomical characters in Cussonia and related genera (Araliaceae). Botanical Journal of the Linnean Society. 164(3):246-263.

[40] Badiaga, M. 2011 Etude ethnobotanique, phytochimiqueetactivitésbiologiques de Nauclealatifolia Smith, uneplantemédicinaleafricainerécoltée au Mali. Bamako: Universite de Bamako - Université Blaise Pascal Clermont-Ferrand II.

[41] Onocha, P. A., Otunla, E. O.2010 Biological activities of extracts of Pycnanthusangolensis (Welw.)Warb. 2(4):186-190.

[42] Ofori, K. A.2004Analgesic and other pharmacological actions of extracts from the seeds of Picralimanitida in rats. Accra: Kwame Nkrumah University of Science and Technology.

[43] Mabeku, L. B. K., Kouam, J., Beng, V. P., Ngadjui, B. T., Fomum, Z. T., Etoa,F. X. 2005 Evaluation of antimicrobial activity of the fruit rind of Picralimanitida (Aapocynaceae) and the stem bark of Cylicodscusgabunensis (Mimosaceae). West African Journal of Pharmacology and Drug Research. 21 (1\&2): 612.

[44] Fernandez-Panchon, M. S., Villano, D., Troncoso, A. M., Garcia-Parrilla, M. C. 2008 Antioxidant activity of phenolic compounds: from in vitro results to in vivo evidence. Critical reviews in food science and nutrition 48(7):649-671.

[45] Shahidi, F., Wanasundara, P. K.1992Phenolic antioxidants. Critical reviews in food science and nutrition 32(1):67-103.

[46] Scalbert, A.,Manach, C., Morand, C., Remesy, C., Jimenez, L. 2005 Dietary polyphenols and the prevention of diseases. Critical reviews in food science and nutrition. 45(4):287-306.

[47] Scalbert, A., Johnson, I. T., Saltmarsh, M. 2005 Polyphenols: antioxidants and beyond. The American journal of clinical nutrition. 81(1 Suppl):215S-217S.

[48] Namiki, M.1990 Antioxidants/antimutagens in food. Critical reviews in food science and nutrition 29(4):273-300.

[49] Higdon, J. V., Frei, B.2006Coffee and health: a review of recent human research. Critical reviews in food science and nutrition 46(2):101-123.

[50] Sarria, B., Mateos, R., Gallardo, E., Ramos, S., Martin, M. A., Bravo, L., Goya, L. 2012Nitroderivatives of olive oil phenols protect HepG2 cells against oxidative stress. Food and chemical toxicology: an international journal published for the British Industrial Biological Research Association. 50(10):3752-3758.

[51] Martin, M. A., Ramos, S., Cordero-Herrero, I., Bravo, L., Goya, L. 2013 Cocoa phenolic extract protects pancreatic beta cells against oxidative stress. Nutrients5(8):2955-2968. 
[52] D'Angelo, S., Cimmino, A., Raimo, M., Salvatore, A., Zappia V., Galletti, P. 2007 Effect of reddening-ripening on the antioxidant activity of polyphenol extracts from cv. 'Annurca' apple fruits. Journal of agricultural and food chemistry 2007, 55(24):9977-9985.

[53] Barrera, G. 2012 Oxidative stress and lipid peroxidation products in cancer progression and therapy. ISRN oncology:137289.

[54] Fulda, S., Gorman, A. M., Hori, O., Samali,A.: Cellular stress responses: cell survival and cell death. International journal of cell biology 2010, 2010:214074.

\section{Author' biography with Photo}

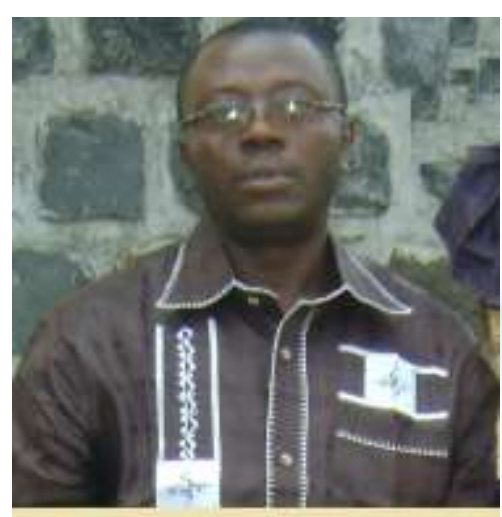

Dr Jules Clement Nguedia Assob completed his PhD in Medical Biochemistry from the University of Yaoundé I in Cameroon. He is the Head of Department of Medical Laboratory Sciences of the Faculty of Health Sciences at the University of Buea. He has published more than 50 papers in reputed revues and is serving as Editorial Board memberin many journals. He is a fellow ofthe International Foundation for Sciences since 2007 . His fields of research are: Ethnopharmacology; Clinical Biochemistry, Chemotherapy of Infectious Diseases. 